\title{
HOW ORGANIZED HEALTH CARE FACILITIES GAIN LEVERAGE OVER PRACTICING PHYSICIANS
}

\author{
Dr. Vijith Gunasekera*
}

Health care managers have never had the ability to exercise leverage over the most priceless resources of land, labour, capital and entrepreneurship. However, it is the physicians who determine the influx of business as they admit patients, which ultimately is the vital factor for the hospital's existence in the competitive business environment in order to maintain economic viability.

The fiscal capacity of the hospital is now being shifted away from health care providers to clients who demand services and are ready to pay for it. Therefore, this shift has compelled the hospital administrators and medical staff to rethink and redesign their processes accordingly, without compromising the quality. These scenarios are not so imperative in the public sector, since the delivery of care is not directly linked to monitory gains or profits. In the West, hospitals and physicians are losing their monopolies on inpatient care services which they had taken for granted. Alternative ways and means of delivering diagnostic services, emergency care, surgery and other support services, should be thought of and investments channeled in an unconventional direction to achieve more.

Health care managers and administrators in the public sector and private sector are beginning to understand that the marketplace for health care is vulnerable and is dependent on mutual provision of better services to the patient. In this backdrop, public private partnerships would be an ideal solution to improvement of services in both sectors.

Richard Reece explains the elemental fact that the course of events over the last 24 years has shown that hospitals are steadily gaining leverage over physicians, and not the other way around. Main factors determining leverage include: increasing complexity of the systems, complicated contract negotiations, declining physician reimbursements, growth of large hospital systems, malpractice premium, growing trend of litigation, utilization reviews requiring physicians to justify testing and procedures, more and more demand for high tech interventions and need of expertise to manage in a competitive environment which is sensitive to market forces and also deals with complex rules and regulations due to health reforms. (Richard R, 2012).

Public trust is a main factor that promotes leverage. As the late Peter F. Drucker (1909-2005) observed, "Every single social task of major impact is increasingly entrusted to institutions which are organized for perpetuity and which are managed by professionals, whether they be called managers, administrators, or executives." This trust is being increasingly invested in large organizations.

According to Victor Fuchs, a Stanford economist and proponent of universal health care, systems entirely depend on management. As he noted, "the most significant battleground is between practicing physicians and management. By that I mean the inevitable clash between a fiercely independent profession and a management system that seeks firmer control over what physicians do." Therefore, it is noteworthy that administrative competence brings about leverage on organized health care facilities over individual operations. Factors such as politics, be it external (regional or local government) or internal (physician politics), largely determine and influence the outcomes of an organization.

In general, medically qualified managerial professionals, with administrative and entrepreneurial skills, lead organizations better and the systems led by them tend to be successful. This may lead to improvement in the health care, quality and cost effectiveness of services to the patients.

\section{References}

Richard R, 2012,

http://medinnovationblog.blogspot.com/2012/01/hospita ls-gaining-leverage-over.html

Richard R,"Obama, Doctors, and Health Reform: ADoctor Assesses the Odds for Success, 2011

Victor R. Fuchs, Health Care Is Different-That's Why Expenditures Matter, Journal of the American Medical Association, Vol. 303, page(s) 18. 